УДК 342.951

DOI https://doi.org/10.32849/2663-5313/2020.12.23

\title{
Андрій Веліканов,
}

аспірант кафедри адміністративного права та адміністративної діяльності

Національного юридичного університету імені Ярослава Мудрого

\section{ЗМІСТ ПУБЛІЧНИХ ЕЛЕКТРОННИХ ПОСЛУГ У СФЕРІ ОХОРОНИ ЗДОРОВ'Я}

У статті розглянуто сутність та зміст надання публічних електронних послуг у сфері охорони здоров’я в аспекті розвитку науки адміністративного права та теорії публічного адміністрування. Проаналізовано правові категорії «публічний інтерес», «послуги», «публічні послуги», «електронні публічні послуги», «адміністративні послуги», «адміністративні електронні послуги», «медичні послуги». Запропоновано власне визначення поняття «публічні електронні послуги у сфері охорони здоров'я», а саме як адміністративної або іншої публічної послуги, що надається в електронній формі із застосуванням спеціалізованих інформачійно-комунікаиійних систем на платній чи безоплатній основі фізичній або юридичній особі суб'єктами, спеціально уповноваженими державою органами відповідно до закону $і$ не потребує особистого контакту між отримувачем та надавачем послуги на окремих стадіях отримання послуги або протягом усієї прочедури. З’ясовано, що публічні послуги сфери охорони здоров'я надаються публічним сектором, за рахунок публічних коштів, за їх надання відповідальність несе публічна влада. Наведено, що залежно від суб'єкта, що надає публічні послуги, розрізняють державні та муніципальні послуги. Встановлено, що адміністративні послуги у сфері охорони здоров'я є одним із різновидів публічних послуг. Запропоновано під адміністративними послугами сфери охорони здоров'я розуміти функиію публічного адміністрування сервісного спрямування, спрямовану на створення належних умов державою (відповідно до закону) з метою реалізачії фізичними та юридичними особами (за заявою) своїх прав, результатом якої є юридичне оформлення набуття, зміни чи припинення прав та/або обов'язків такої особи у сфері охорони здоров'я.

Аргументовано, що публічні електронні послуги у сфері охорони здоров'я є одним із різновидів інструментів публічного адміністрування. Зроблено висновок, що у правовій демократичній державі надання органами публічної влади якісних публічних електронних послуг у сфері охорони здоров'я повинно бути пріоритетним завданням. Публічні електронні послуги у сфері охорони здоров'я є одним із різновидів інструментів публічного адміністрування.

Ключові слова: публічні електроні послуги, охорона здоров'я, адміністративно-правове регулювання, адміністративні електроні послуги, медичні послуги, публічний інтерес.

Постановка проблеми. В Україні, як асоційованому члені Європейського Союзу, метою державної політики у сфері охорони здоров'я $є$ кардинальне, системне реформування, спрямоване на створення системи, орієнтованої на пацієнта, здатної забезпечити медичне обслуговування для всіх громадян України на рівні розвинутих європейських держав [1], одним із напрямів проведення медичної реформи є удосконалення надання публічних електронних послуг у сфері охорони здоров'я, тому розвиток держави на шляху європейської інтеграції неможливий без усунення правових проблем у цьому напрямі. Серед основних проблем сфери охорони здоров'я України є: відставання України від європейських країн за показниками тривалості життя та смертності; відсутність своєчасної та стандартизованої інформації про пацієнта у лікарів; використання закладами охорони здоров'я неефективних інструментів, що пов'язано
3 веденням великої кількості паперових форм медичної документації; фрагментарність інформації про стан здоров'я пацієнта; збереження первинної медичної інформації у різних надавачів медичних послуг; обмежена доступність медичних послуг; непрозорість системи охорони здоров'я, недостовірні дані та корупція тощо.

Аналіз останніх досліджень і публікацій. Проблеми надання адміністративних послуг досліджували такі вчені, як В. Б. Авер'янов, Ю. П. Битяк, В. Я. Настюк, І. В. Бойко, О. М. Буханевич [2], Н. Б. Писаренко, О. Т. Зима, О. М. Соловйова [3], В. П. Тимощук, І. Б. Коліушко та ін. Так, О. А. МузикаСтефанчук зі співавторами розкрила окремі правові аспекти надання публічних адміністративних послуг у сфері охорони здоров'я [4], I. В. Венедіктова вивчила специфіку надання публічних послуг в медичній сфері [5], О. М. Шевчук зі співавторами з'ясував особливості правового регулювання надання 
медичних послуг [6] та ін. В Україні активно функціонують «E-Zdorovya», «e-Health», «e-Helsi», що включає використання електронних рецептів і медичних карт, електронних медичних історій пацієнтів. Однак питання стосовно з'ясування змісту та сутності публічних електронних послуг у сфері охорони здоров'я як адміністративно-правової категорії в наукових джерелах не розкрито, що вказує на актуальність даної роботи та їі практичне значення.

Метою статті є з'ясування змісту публічних електронних послуг у сфері охорони здоров'я як адміністративно-правової категорії.

Виклад основного матеріалу. У положеннях Конституції України найвищою соціальною цінністю є людина, іï життя і здоров'я, честь та гідність [7], що стало основним стимулом до активізації процесів розбудови публічно-сервісної держави. О. В. Карпенко пропонує сервісну діяльність органів державної влади розглядати як пріоритетний напрям розвитку державного управління в Україні, сутність якого полягає в наданні управлінських послуг громадянам, які $є$ їх одержувачами - клієнтами держави (вигодонабувачами), а державні службовці й посадові особи органів місцевого самоврядування $€$ надавачами (виконавцями), що реалізують ці послуги від імені держави [8, с. 11]. Так, В. Б. Авер'янов зазначив, що «у результаті трансформації адміністративного права на засадах «людиноцентристської» ідеології ця галузь має стати основним засобом гармонізації відносин між публічною владою і людиною» [9, с. 238]. У розвитку публічно-сервісної діяльності держави окреме місце займає надання публічних електронних послуг у сфері охорони здоров'я. Розкриваючи зміст цієї правової конструкції, треба вказати на розуміння «публічного інтересу» як категоpiї адміністративного права. Так, М. М. Тернущак публічний інтерес розуміє як складник публічного управління, вважаючи його метою, самоціллю, кінцевим результатом публічно-адміністративної діяльності [10, с. 283]. М. І. Васильєва визначає, що публічні інтереси відображають державні, якщо вони задовольняють потреби суспільства [11, с. 64]. Л. О. Золотухіна під публічним інтересом розуміє сукупність потреб, прагнень учасників суспільних відносин, що визнаються державою, реалізація яких гарантуються засобами публічного управління та сприяє забезпеченню прав і свобод людини. Належне забезпечення реалізації публічного інтересу визначає рівень ефективності функціонування органів державної влади та місцевого самоврядування, характеризує рівень розвитку суспільства [12 с. 147, 148]. В основному ми погоджуємось з вищенаведеною думкою автора. Наступним складовим елементом правової конструкції «публічних електронних послуг у сфері охорони здоров'я» є термін «публічні послуги». У свою чергу, поняття «послуга» у словниковій літературі визначено як «дія, вчинок, що дає користь, допомогу іншому; 2) робота, виконувана для задоволення чиїх-небудь потреб; обслуговування» [13]. Закон України «Про захист прав споживачів» визначає послугу як діяльність виконавця з надання (передачі) споживачеві певного визначеного договором матеріального чи нематеріального блага, що здійснюється за індивідуальним замовленням споживача для задоволення його особистих потреб (п. 17 ч. 1 ст. 1) [14] У положеннях Концепції розвитку системи надання адміністративних послуг органами виконавчої влади вказується, які послуги становлять сферу публічних послуг. До цієї сфери відносять послуги, що надаються органами державної влади, органами місцевого самоврядування, підприємствами, установами, організаціями, які перебувають в їх управлінні [15]. Так, на думку, І. В. Венедіктової, термін «публічна послуга» слід розуміти як суспільно значущу, чітко регламентовану законодавством діяльність, для якої характерним є добровільний інтерес споживача послуги та індивідуальний характер її надання будь-якій особі, яка має на це право або звертається за реалізацією своїх прав, свобод і законних інтересів, на рівних підставах безоплатно або в межах цін, що визначені державою [16, с. 10]. 3 погляду І. Б. Коліушка та В. П. Тимощука, «публічними є всі послуги, які надаються публічним сектором, за рахунок публічних коштів та за надання яких відповідальність несе публічна влада» [17, с. 117]. Отже, взявши за основу вищенаведену позицію, зазначимо, що публічні послуги у сфері охорони здоров’я надаються публічним сектором, за рахунок публічних коштів, за їх надання відповідальність несе публічна влада. При цьому сфера охорони здоров'я - це система заходів, спрямованих на забезпечення збереження і розвитку фізіологічних і психологічних функцій, оптимальної працездатності та соціальної активності людини при максимальній біологічно можливій індивідуальній тривалості життя. (ч. 1 ст. 3) [18].

Питанням надання «електронних послуг» приділяли увагу О. О. Берназюк, І. О. Тищенкова, Е. Г. Шевчук та ін. Так, Е. Г. Шевчук у кандидатській дисертації з'ясував особливості надання безконтактних адміністратив- 
них послуг у сфері державного архітектурнобудівельного контролю та нагляду [19]. У загальному розумінні існують такі погляди на термін «адміністративна послуга»: (1) це «публічні послуги, що надаються органами виконавчої влади, виконавчими органами місцевого самоврядування та іншими уповноваженими суб'єктами, і надання яких пов'язане 3 реалізацією владних повноважень щодо ухвалення згідно 3 нормативноправовими актами на звернення юридичної або фізичної особи адміністративного акту, спрямованого на реалізацію та захист її прав і законних інтересів та/або на виконання особою визначених законом обов'язків отримання дозволу (ліцензії), сертифіката посвідчення та інших документів, реєстрації тощо» (Н. М. Мариняк) [20, с. 63]; (2) «функція публічного управління як обов'язок держави перед приватними особами зі створення необхідних умов для того, щоб фізична особа могла в повному обсязі реалізувати свої права чи законні інтереси» (І. Л. Бородін та Р. А. Калюжний) [21, с. 169]; (3) функція публічного адміністрування сервісного спрямування, яка полягає у створенні належних умов державою для реалізації фізичними та юридичними особами своїх суб'єктивних прав (Е. Г. Шевчук) [22, с. 43]; (4) «публічні (тобто державні та муніципальні) послуги, що надаються органами виконавчої влади, виконавчими органами місцевого самоврядування й іншими уповноваженими суб'єктами і надання яких пов'язане з реалізацією владних повноважень» (К. К. Афанасьєв) [23, с. 28]. Отже, залежно від суб'єкта, що надає публічні послуги у сфері охорони здоров'я, слід розрізняти державні та муніципальні послуги. Важливими їх складниками є адміністративні послуги. Адміністративні послуги у сфері охорони здоров'я є одним із різновидів публічних послуг.

На думку О. А. Музики-Стефанчук, «адміністративна послуга у сфері охорони здоров'я» - це результат здійснення владних повноважень уповноваженим суб'єктом, який реалізує публічні функції у сфері охорони здоров'я та відповідно до закону й за заявою фізичної або юридичної особи забезпечує юридичне оформлення набуття, зміни чи припинення прав та/або обов'язків такої особи» [24, с. 263]. 3 нашого погляду, адміністративні послуги у сфері охорони здоров'я слід розуміти як функцію публічного адміністрування сервісного спрямування, спрямовану на створення належних умов державою (відповідно до закону) з метою реалізації фізичними та юридичними особами (за заявою) своїх прав, результатом якої $є$ юридичне оформлення набуття, зміни чи припинення прав та/або обов'язків такої особи у сфері охорони здоров'я. О. А. Музика-Стефанчук пропонує розмежовувати медичні послуги та адміністративні послуги у сфері охорони здоров'я [25, с. 263]. У статі 1 Закону України «Основи законодавства України про охорону здоров'я» медична послуга визначається як послуга, що надається пацієнту закладом охорони здоров'я або фізичною особою-підприємцем, яка зареєстрована та одержала в установленому законом порядку ліцензію на провадження господарської діяльності з медичної практики, та оплачується її замовником. Замовником послуги 3 медичного обслуговування населення можуть бути держава, відповідні органи місцевого самоврядування, юридичні та фізичні особи, у тому числі пацієнт [26]. Натомість С. В. Антонов визначає медичну послугу як «вид професійної або господарської діяльності медичних закладів (організацій), фізичних осібпідприємців, які займаються приватною практикою, що включає застосування спеціальних заходів стосовно здоров'я (результатом яких $є$ поліпшення загального стану, функціонування окремих органів або систем організму людини) чи спрямованих на досягнення певних естетичних змін зовнішності» [27, с. 21]. О. М. Шевчук під «медичною послугою» розуміє корисну діяльність постачальника послуг, яка спрямована на задоволення потреб здоров'я людини. Ця послуга спрямована на діагностику, лікування або профілактику захворювання, реабілітацію та надання медичної допомоги, пов'язаної з вагітністю, пологами, і підлягає ліцензуванню [28 с. 364]. Із вищенаведеною позицію ми погоджуємось.

Щодо змісту публічних електронних послуг у сфері охорони здоров'я. У положеннях Концепцією розвитку електронного урядування в Україні електронна (або е-послуга) визначена як «адміністративна або інша публічна послуга, що надається громадянину або юридичній особі в електронній формі [29]. Закон України «Про електронні довірчі послуги» визначає електронну послугу як будь-яку послугу, що надається через інформаційно-телекомунікаційну систему (ст.) [30]. Розпорядженням КМ України від 15 лютого 2006 року № 90-р затверджено Концепцію розвитку системи надання адміністративних послуг органами виконавчої влади [31]. Згідно з положеннями цієї Концепції, адміністративні послуги, які $є$ складовою частиною публічних послуг, - це «результат здійснення владних повноважень уповноваженим суб'єктом, що відповідно до закону забезпечує юридичне оформлення умов реалізації фізичними та юридичними 
особами прав, свобод і законних інтересів за їх заявою (видача дозволів (ліцензій), сертифікатів, посвідчень, проведення реєстрації тощо)» [32]. Зокрема, I. О. Тищенкова вважає, що електронними послугами в діяльності публічної адміністрації слід розуміти «правовідносини, що виникають завдяки інформаційно-комунікаційним технологіям 3 приводу реалізації суб'єктивних прав фізичної чи юридичної особи переважно за їх заявою у процесі публічно-владної діяльності публічної адміністрації» [33, с. 17]. На думку O. О. Берназюк, електронна адміністративна послуга являє собою «адміністративну послугу, яка повністю або частково надається за допомогою онлайн-сервісів» [34, с. 198]. Отже, публічна електронна послуга у сфері охорони здоров'я - це адміністративна або інша публічна послуга, що надається в електронній формі із застосуванням спеціалізованих інформаційно-комунікаційних систем на платній чи безоплатній основі фізичній або юридичній особі суб'єктами, спеціально уповноваженими державою органами відповідно до закону і не потребує особистого контакту між отримувачем та надавачем послуги на окремих стадіях отримання послуги або протягом усієї процедури. Публічні електронні послуги у сфері охорони здоров'я є одним із різновидів інструментів публічного адміністрування. У цьому контексті особливої уваги заслуговує впровадження системи «E-Health»- електронної системи охорони здоров'я, що забезпечує обмін медичною інформацією та реалізацію програми медичних гарантій населенню [35]. Наприклад, уже впроваджено послугу «електронний рецепт», яка функціонуе на ресурсі «Доступні ліки». Розглянемо її докладніше. На сайті МОЗ України розміщена чітка інструкція для лікарів з видачі електронного рецепту пацієнтам, якою регламентовано використання електронної картки пацієнта, що є найбільш зручним для лікаря, адже мінімізує можливість помилок. Алгоритм дій виглядає так: пацієнт приходить до лікаря; лікар відкриває його е-картку та у відповідному розділі вибирає «Виписати рецепт»; заповнюе інформацію про лікарський засіб у відповідних електронних формах: «Міжнародна непатентована назва ліків», «Дозування», «Лікарська форма», «Кількість доз», «Спосіб вживання ліків»; перевіряє правильність номеру телефона пацієнта, а потім лікар накладає свій ЕЦП або КЕП. Далі пацієнту приходить СМС із номером рецепта та кодом підтвердження. Після чого пацієнт вибирає аптеку з тих, що підписали договори з НЗСУ, та без паперового варіанту, маючи лише номер та код підтвердження у вигляді СМС, прямує отримувати ліки [36].

Аналізуючи формат надання інформаційних та інших послуг з використанням електронної інформаційної системи «Електронний Уряд», можна вирізнити чотири види електронного надання інформаційної послуги: (1) інформування (надання безпосередньо інформації про державні (адміністративні) послуги); (2) одностороння взаємодія (забезпечена можливість користувачу отримати електронну форму документа); (3) двостороння взаємодія (забезпечена можливість обробки електронної форми документа, включаючи ідентифікацію); (4) проведення трансакцій (електронна реалізація можливостей прийняття рішень та їх доставка) [37] Завдання та функціональні можливості електронної системи охорони здоров'я визначені Порядком функціонування електронної системи охорони здоров'я, затвердженим Постановою КМ України від 25 квітня 2018 р. № 411. Так, згідно 3 п. 7 даного Порядку, завданням електронної системи охорони здоров'я є забезпечення можливості використання пацієнтами електронних сервісів для реалізації їхніх прав, зокрема, за програмою державних гарантій медичного обслуговування населення, автоматизація ведення обліку медичних послуг і управління медичною інформацією, запровадження електронного документообігу у сфері медичного обслуговування населення. Відповідно до п. 8 Порядку, функціональні можливості електронної системи охорони здоров'я повинні забезпечувати: (1) можливість реєстрації користувачів у центральній базі даних, у тому числі з використанням засобів електронної ідентифікації; розмежування прав користувачів на внесення, перегляд інформації у центральній базі даних, внесення змін та доповнень до неї; (2) можливість створення, внесення, перегляду та обміну деклараціями про вибір лікаря, який надає первину медичну допомогу, рецептами, направленнями, медичними записами, іншою інформацією та документами через електронні кабінети відповідно до прав доступу користувачів; (3) можливість використання електронної системи охорони здоров'я особами 3 порушенням зору та слуху; (4) можливість надання пацієнтами (ix законними представниками) згоди у письмовій формі або у формі, що дає змогу зробити висновок про надання згоди, на доступ до даних про себе (про пацієнта для законних представників), що міститься в електронній системі охорони здоров'я, лікарям, третім особам; (5) отримання пацієнтами відомостей про осіб, які подавали запити щодо надання інформації, 
що міститься в електронній системі охорони здоров’я, про таких пацієнтів; (6) здійснення пошуку та перегляду відомостей у центральній базі даних відповідно до прав доступу користувача $з$ дотриманням вимог Закону України «Про захист персональних даних» можливість укладення, зміни та припинення договорів про медичне обслуговування населення та договорів про реімбурсацію за програмою медичних гарантій, формування та подання електронних звітів, первинних, розрахункових та інших документів за договорами через центральну базу даних [38].

\section{Висновки}

у правовій демократичній державі надання органами публічної влади якісних публічних електронних послуг у сфері охорони здоров'я повинно бути пріоритетним завданням. Публічні електронні послуги у сфері охорони здоров'я є одним із різновидів інструментів публічного адміністрування. Публічна електронна послуга у сфері охорони здоров'я це адміністративна або інша публічна послуга, що надається в електронній формі із застосуванням спеціалізованих інформаційно-комунікаційних систем на платній чи безоплатній основі фізичній або юридичній особі суб'єктами, спеціально уповноваженими державою органами відповідно до закону і не потребує особистого контакту між отримувачем та надавачем послуги на окремих стадіях отримання послуги або протягом усієї процедури.

\section{Список використаних джерел:}

1. Стратегію сталого розвитку «Україна - 2020» : Указ Президента України від 12 січня 2015 року № 5/2015. Офіиійний вісник України. 2015. № 4. Ст. 67.

2. Буханевич О. М. Адміністративні послуги в Україні: теорія та практика реалізації : монографія. Київ : Ін-т законодавства Верховної Ради України, 2015. 385 с.

3. Соловйова О.Н. Требования к качеству административных услуг. Legea si Viata. 2015. C. 95-99.

4. Музика-Стефанчук О.А. Публічні адміністративні послуги у сфері охорони здоров'я Запорізький медичний журнал. 2020. Т. 22 № 2(119). С. 261-266.

5. Венедіктова І.В. Публічні послуги в медичній сфері. Медичне право. 2009. № 3. С. 7-14.

6. Shevchuk O. et. al. Aspects of legal regulation of the provision of medical services. Amazonia investiga. 2020. Vol. 9. Issue 27. P. 357-366.

7. Конституція України від 28.06.1996 р. № 254к/96-ВР. Відомості Верховної Ради України. 1996. № 30. Ст. 141.

8. Карпенко О.В. Механізм формування та реалізації сервісно-орієнтованої державної полі- тики в Україні : дис. ... докт. наук з держ. управл. : 25.00.02. Київ, 2016. 466 с.

9. Державне управління: європейські стандарти, досвід та адміністративне право. Авер'янов В. Б., Дерець В. А., Школик А. М. та ін.; за заг. ред. Авер'янова В.Б. Київ: Юстініан, 2007. 287 c.

10. Тернущак М. М. Зміст категорії «публічний інтерес» в адміністративно-судочинському провадженні. Порівняльно-аналітичне право. 2015. № 4. C. 282-283. URL: http://www.pap. in.ua/4_2015/86.pdf (дата звернення: 04.12.2020).

11. Васильева В. И. Публичные интересы в экологическом праве. Москва: МГУ, 2003. 424 с.

12. Золотухіна Л. О. Публічний інтерес як адміністративно-правова категорія : дисер. ... докт. юрид. наук : 12.00.07. Запоріжжя: Запорізький національний університет, 2019. 486 с.

13. Словник української мови : в 11 т. / за ред. I. К. Білодіда. Київ : Наукова думка, 1970-1980. URL: http://ukrlit.org/slovnyk/slovnyk_ukrainskoi movy v 11 tomakh (дата звернення: 05.12.2020).

14. Про захист прав споживачів : Закон України від 12.05.1991 № 1023-XII. Відомості Верховної Ради УРСР. 1991. № 30. Ст. 379.

15. Про затвердження Концепції розвитку системи надання адміністративних послуг органами виконавчої влади : розпорядження КМ України від 15.02.2006 р. № 90-p. URL : https://zakon.rada. gov.ua/laws/show/90-2006-\%D1\%80?lang=uk. (дата звернення: 05.12.2020).

16. Венедіктова І.В. Публічні послуги в медичній сфері. Медичне право. 2009. № 3. С. 7-14.

17. Науково-практичний коментар до Закону України «Про адміністративні послуги» / за заг. ред. В.П. Тимощука. Київ: ФОП Москаленко О.М. $392 \mathrm{c.}$

18. Основи законодавства України про охорону здоров'я : Закон України від 10.11.1992 р. № 2801-XII. Відомості Верховної Ради України. 1993. № 4. Ст. 19.

19. Шевчук Е.Г. Безконтактні адміністративні послуги у сфері державного архітектурно-будівельного контролю та нагляду : дис. ... канд. юрид. наук : 12.00.07. Запоріжжя, 2020. 195 с.

20. Мариняк Н. М. Адміністративна послуга та її співвідношення з суміжними поняттями. Вісник Начіонального університету «Львівська політехніка». Серія «Юридичні науки». 2015. № 824. С. $60-64$.

21. Бородін І., Калюжний Р. Адміністративна послуга - функція публічного управління. Evropsky politicky a pravni diskurz. 2015. Vol. 2, Iss. 3. C. 168-173.

22. Шевчук Е.Г. Безконтактні адміністративні послуги у сфері державного архітектурно-будівельного контролю та нагляду : дис. ... канд. юрид. наук: 12.00.07. Запоріжжя, 2020. 195 с.

23. Афанасьєв К.К. Адміністративні послуги : навчальний посібник. Луганськ : РВВ ЛДУВС ім. Е. О. Дідоренка, 2010. 175 с.

24. Музика-Стефанчук, О.А. Публічні адміністративні послуги у сфері охорони здоров’я. 
Запорізький медичний журнал. 2020. Т. 22. № 2(119). С. 261-266.

25. Музика-Стефанчук О.А. Публічні адміністративні послуги у сфері охорони здоров'я. Запорізький медичний журнал. 2020. Т. 22. № 2(119). С. 261-266.

26. Основи законодавства України про охорону здоров'я : Закон України від 10.11.1992 р. № 2801-XII. Відомості Верховної Ради Украӥни. 1993. № 4. Ст.19.

27. Антонов С. В. Правова регламентація надання медичних послуг. Управління закладом охорони здоров'я. Київ, 2007. С. 18-22.

28. Shevchuk O. et. al. Aspects of legal regulation of the provision of medical services. Amazonia investiga. 2020. Vol. 9. Issue 27. P. 357-366.

29. Про схвалення Концепції розвитку системи надання адміністративних послуг органами виконавчої влади : розпорядження КМ України від 15.02.2006 № 90-p. URL: https://zakon.rada. gov.ua/laws/show/90-2006-\%D1\%80\#Text (дата звернення: 04.12.2020).

30.Закон України про електронні довірчі послуги від 05.10.2017 № 2155-VIII. URL: https:// zakon.rada.gov.ua/laws/show/2155-19 (дата звернення: 04.12.2020)

31. Про затвердження Концепції розвитку системи надання адміністративних послуг органами виконавчої влади : розпорядження КМ України від 15.02.2006 р. № 90-p. URL : https://zakon.rada. gov.ua/laws/show/90-2006-\%D1\%80?lang=uk (дата звернення: 04.12.2020).
32. Про затвердження Концепції розвитку системи надання адміністративних послуг органами виконавчої влади : розпорядження КМ України від 15.02.2006 р. № 90-p. URL : https://zakon.rada. gov.ua/laws/show $/ 90-2006-\%$ D1\%80?lang $=u k$ (дата звернення: 04.12.2020)

33. Тищенкова I. О. Електронні послуги у діяльності публічної адміністрації України : монографія. Дніпро : Дніпроп. держ. ун-т внутр. справ, 2017. $156 \mathrm{c}$.

34. Берназюк О. Адміністративні електронні послуги: поняття та умови впровадження в Україні. Підприємниитво, господарство і право. 2019. № 5. C. 196-199.

35. Helsi Реформа». Про Helsi. URL: https:// reform.helsi.me/about-us (дата звернення: 04.12.2020)

36. Як виписувати електронний рецепт на «Доступні ліки»: інструкція для лікарів. URL https://moz.gov.ua/article/for-medical-staff/jakvipisuvati-elektronnij-recept-na-dostupni-likiinstrukcija-dlja-likariv (дата звернення: 4.12.2020)

37. Порядок надання інформаційних та інших послуг з використанням електронної інформаційної системи «Електронний Уряд» : наказ Державного комітету зв'язку та інформатизації України від 16 серпня 2003 р. № 149. URL: http://zakon2. rada.gov.ua/laws/show/z1066-03 (дата звернення: 04.12.2020).

38. Деякі питання електронної системи охорони здоров'я. URL: https://zakon.rada.gov.ua/ laws/show/411-2018-\%D0\%BF\#Text (дата звернення: 04.12.2020)

\section{Andrii Velikanov. The essence of public electronic services in the health care}

The article reviews the essence and content of public electronic services providing in the field of health care in terms of development in field of administrative law science and the theory of public administration. The legal categories of "public interest", "services", "public services", "electronic public services", "administrative services", "administrative electronic services", "medical services" were analyzed.

The own definition of "public electronic services in the field of health care" was proposed, and here it follows: administrative or any public service provided in electronic form using specialized information and communication systems on a paid or free basis for individuals or legal entities, which are authorized by the state in accordance with the law and does not require any personal contact between the recipient and the service provider within certain stages or throughout the procedure.

There was disclosed that public health services are provided by the public sector, at the expense of public funds and for the provision of which public authorities are responsible. Also, it is stated that depending on institution providing public services, there are state and municipal services. Administrative services in the field of health care have been identified as a type of public services. It is suggested that administrative services in the field of health care should be understood as a service related function of public administration, aimed on creating appropriate conditions by the state (according to the law) for individuals and legal institutions (using application) for realization of their rights, legal registration of acquisition, change or termination of such rights and / or obligations of such person in the field of health care. It is proven that public e-health services are one of public administration tools. It is concluded that in a state governed by the rule of law, the provision of quality public e-health services must be considered as a priority task.

Key words: public electronic services, health care, administrative and legal regulation, administrative electronic services, medical services, public interest. 